(C) Telkom University

INTERNATIONAL JOURNAL OF INNOVATION IN ENTERPRISE SYSTEM

Journal homepage: https://ijies.sie.telkomuniversity.ac.id/index.php/IJIES/index

e-ISSN: 2580-3050

\title{
Key Factors in Improving the Maturity of Information Technology Governance: A Case Study of State-owned Enterprise in Indonesia
}

\author{
Rokhman Fauzi $^{{ }^{*}}$, Rahmat Mulyana ${ }^{2}$ \\ ${ }^{1}$ Telkom University \\ Jalan Telekomunikasi Terusan Buah Batu, Bandung, 40257, INDONESIA \\ ${ }^{2}$ Telkom University \\ Jalan Telekomunikasi Terusan Buah Batu, Bandung, 40257, INDONESIA \\ *rokhmanfauzi@telkomuniversity.ac.id
}

\section{ARTICLE INFO}

Article history:

Received 30 April 2020

Accepted 24 July 2020

Published 30 July 2020

Keywords:

IT governance, maturity assessment, critical success factors, State-owned Enterprise, IT quality

\begin{abstract}
A B S T R A C T
The assessment of IT governance maturity is part of the assurance function. The assessment is carried out to ensure technology support in achieving business goals. In this context, companies should comply with regulations, as well as the need to continue to improve the quality of implementation of IT governance. The average value of PT X's IT governance maturity in Year 2 has increased from 3.21 to 3.26 . There is an increase in the average score of 0.05 over one year. Success factors in implementing IT governance must be maintained and encouraged to continue the grow. This research was conducted to identify what organizational initiatives to increase the maturity and what the key factors are. Factors identification is done using evidence analysis method based on CSF references and attributes criteria. The results of the analysis obtained key factors that strengthen the maturity. The main factors are CSF2 providing IT infrastructure that supports the development and exchange of IT applications and services (21.72\%), and CSF4 staff development to meet professional IT HR qualifications (17.39\%). On the other hand, maturity attribute which gave the biggest contribution was ATR1 related to policies and procedures (34.6\%), and ATR3 related to defining goals and actions (30.77\%).
\end{abstract}

\section{Introduction}

Information Technology has enormous benefits in developing a company's business, so it needs to be developed in a directed and measurable way. Information technology for many companies is the core of business implementation so that having good information technology governance will improve the performance and objectives of the company, including increasing revenue, reducing costs, and improving service levels. [1,2]. For State-Owned Enterprises / SOEs, the use of information technology must be based on a governance system, contained in a master plan, and developed in synergy so that information technology can be utilized optimally. This is confirmed in the Minister of SOE RI Regulation No. Per-02 / MBU / 02/2018 concerning the IT Governance Principles of the Ministry of SOEs [3] and No. Per-03 / MBU / 2018 (amendment to the regulation of the Minister of BUMN RI No. Per-02 / MBU / 2013) concerning Guidelines for the Arrangement of BUMN Information Technology Management [4].

The assessment of information technology governance maturity assessment, in general, is part of the implementation of the assurance function on information technology governance. The maturity assessment is carried out to ensure information technology support in achieving business goals. SOEs are targeted to reach the level 3 from scale 5 using the COBIT 4.1 framework [5] 
The assessment of the maturity level is intended to find some description of the conditions, as follows: (i) The suitability of the value obtained by the company for its information technology investment planning, (ii) the suitability of information technology risk control to the company's risk appetite, and (iii) Optimization of managing IT resources owned by the organization. [5]. This research was conducted with the aim of (1) Knowing the development of the maturity level in a state-owned PT. X, and (2) Initial identification of factors increasing the maturity in the SOE.

The assessment of the maturity of PT X's information technology governance is carried out in the annual cycle of evaluation of the level of maturity, namely in the 1st and 2nd years. The scoping maturity of the information technology governance analyzed is 34 Processes contained in the COBIT 4.1 framework, grouped in 4 domains as follows: (a) 10 processes in the Plan \& Organize / PO domain, (b) 7 processes in the Acquire \& Implement domains / AI, (c) 13 processes in the Delivery \& Support / DS domain, and (d) 4 processes in the Monitor \& Evaluate / ME domain.

\section{Related Works}

\subsection{Information Technology Governance}

Information technology governance is an inseparable part of corporate governance that includes the leadership mechanism, structure, and organizational processes to ensure that the application of information technology is in accordance with the company's strategy and objectives [6]. Successful implementation of information technology requires a strong link between business and information technology in organizations in optimizing benefits and reducing the uncertainty of information technology projects [7] [8]. In the government sector, information technology governance has a very important role in overseeing efforts to achieve the goal of implementing technology in an organization [9].

If information technology is managed optimally, the company has a greater opportunity to achieve strategic objectives and enable it to achieve a competitive advantage. Information technology governance in the form of structures that enable compatibility between the company's strategic objectives and good risk control [20]. Thus, information technology governance helps each organization to control and benefit from its information technology practices and investments [10]. These contributions were also obtained by educational institutions and medium-small scale industries [11]

At its most basic definition, information technology governance is the process by which decisions around information technology investments are made. How decisions are made, who makes decisions, who is responsible, and how decisions are measured and monitored are part of information technology governance [12]. Thus, it can be said that information technology governance is a process that directs and controls investments, decisions, and practices related to information technology in organizations to achieve desired goals [10].

\subsection{Information Technology Success Factors}

Information technology governance is primarily responsible for optimizing the use of resources, managing project risks, and implementing information technology. Also, information technology governance can provide good solutions for all organizations, both government and private, to optimize investment and balance the risks associated with information technology [13] [19].

To be successful in implementing information technology governance, companies need to adopt various standards and / or frameworks according to their size, complexity and needs. This standard and / or framework aims to guide the implementation of information technology governance components by their scope and focus. Success factors in implementing information technology governance must be maintained and encouraged to continue to grow. Several standards and information technology governance frameworks mention these success factors implicitly using different terms, such as: enablers, challenges, and so on [10][13].

Nfuka et al (2010) conducted a comparison and analysis of several studies relating to critical success factors in the application of information technology governance. This study identifies 17 factors as summarized in Table 1., below:

Table 1 - Critical Success Factors of Information Technology Governance [13]

\begin{tabular}{|c|c|c|}
\hline CSF Ref ID & CSF Identification & Related Study \\
\hline CSF1 & $\begin{array}{l}\text { Standardize and integrate IT system management so that } \\
\text { information flow runs well and costs can be optimized }\end{array}$ & Guldentops, 2004 \\
\hline CSF2 & $\begin{array}{l}\text { Providing information technology infrastructure that } \\
\text { supports the development and exchange of IT applications } \\
\text { and services }\end{array}$ & ITGI, 2003 \\
\hline $\mathrm{CSF} 3$ & Perform risk management appropriately & ITGI, 2003 \\
\hline CSF4 & Conduct staff development to fit IT professional criteria & $\begin{array}{l}\text { Weill, 2004; ITGI, 2003; Teo \& Ang, } \\
1999\end{array}$ \\
\hline CSF5 & Institutionalize and implement policies / guidelines for & Guldentops, 2004; ITGI \& PwC, 2006 \\
\hline
\end{tabular}




\begin{tabular}{|c|c|c|}
\hline CSF6 & $\begin{array}{l}\text { optimizing the use of technology infrastructure and IT } \\
\text { services } \\
\text { Condition and encourage two-way partnership } \\
\text { communication between IT \& business }\end{array}$ & $\begin{array}{l}\text { ITGI \& PwC, 2006; ITGI, 2003; } \\
\text { Luftman et al., 1999; Teo \& Ang, 1999; } \\
\text { Ribbers et al, 2002; De Haes et al., } 2008\end{array}$ \\
\hline CSF7 & $\begin{array}{l}\text { Providing information and education related to IT } \\
\text { governance for strategic to operational levels }\end{array}$ & Weill, 2004; ITGI, Teo \& Ang, 1999 \\
\hline CSF8 & Define and align IT strategies with organizational strategies & $\begin{array}{l}\text { Weill, 2004; Guldentops, 2004; ITGI, } \\
\text { 2003; Luftman et al., 1999; Teo \& Ang, } \\
\text { 1999; Ribbers et al, } 2002\end{array}$ \\
\hline CSF9 & $\begin{array}{l}\text { Use resources effectively to improve IT processes and } \\
\text { business alignment }\end{array}$ & De Haes et al., 2008 \\
\hline CSF10 & Information technology shows leadership & $\begin{array}{l}\text { ITGI, 2003; Luftman et al., 1999; Teo \& } \\
\text { Ang, 1999; De Haes et al., } 2008\end{array}$ \\
\hline CSF11 & $\begin{array}{l}\text { Ensure the active involvement and commitment of the } \\
\text { leadership of the organization }\end{array}$ & $\begin{array}{l}\text { Weill, 2004; Guldentops, 2004; ITGI \& } \\
\text { PwC, 2006; Luftman et al., 1999; Teo \& } \\
\text { Ang, } 1999\end{array}$ \\
\hline CSF12 & $\begin{array}{l}\text { Determine the key decisions that must be made and who is } \\
\text { the most appropriate to make them }\end{array}$ & Weill, 2004 \\
\hline CSF13 & $\begin{array}{l}\text { Clearly institutionalize the decision-making process and } \\
\text { prioritization of IT }\end{array}$ & $\begin{array}{l}\text { Weill, 2004; Guldentops, 2004; Luftman } \\
\text { et al., } 1999\end{array}$ \\
\hline CSF14 & $\begin{array}{l}\text { Institutionalize a structure that ensures accountability \& } \\
\text { flexibility for an organization's IT needs }\end{array}$ & $\begin{array}{l}\text { Weill, 2004; Guldentops, 2004; ITGI, } \\
\text { 2003; De Haes et al., } 2008\end{array}$ \\
\hline CSF15 & Involving key stakeholders & $\begin{array}{l}\text { ITGI, 2003; Teo \& Ang, 1999; Ribbers } \\
\text { et al, } 2002\end{array}$ \\
\hline CSF16 & Institutionalize performance indicators and measurements & $\begin{array}{l}\text { Guldentops, 2004; ITGI \& PwC, 2006; } \\
\text { Luftman et al., 1999; ITGI, } 2003\end{array}$ \\
\hline CSF17 & Manage organizational changes & ITGI \& PwC, 2006 \\
\hline
\end{tabular}

\subsection{Information Technology Governance Maturity Assessment}

The construction of information technology governance mechanisms consists of: IT Decision, Structure, Governance Program, and Maturity \& Performance Measurement [14] [15] [16] [17]. (1) IT decisions are the design or target status of IT decisions, including principles, architectural design, technology infrastructure, application systems, and information technology investments. This pillar is implemented through an IT Strategic Plan, IT Detailed Plan and IT Annual Plan [12]. (2) IT Structure describes what roles must be carried out optimally, how the reporting mechanism is, and how dynamic it is in IT decision making. The structure referred to here is in the form of organizational structure and non-structural functional structures that can be implemented to ensure leadership, participation of all interested work units and IT systems operations [16] [17] [18]. (3) IT Governance Program is a policy, standards, procedures and guidelines in carrying out IT-related activities [15] [17]. (4) IT Maturity \& Performance Measurement is carried out using the IT Governance Maturity Model, which is the maturity of IT Governance.

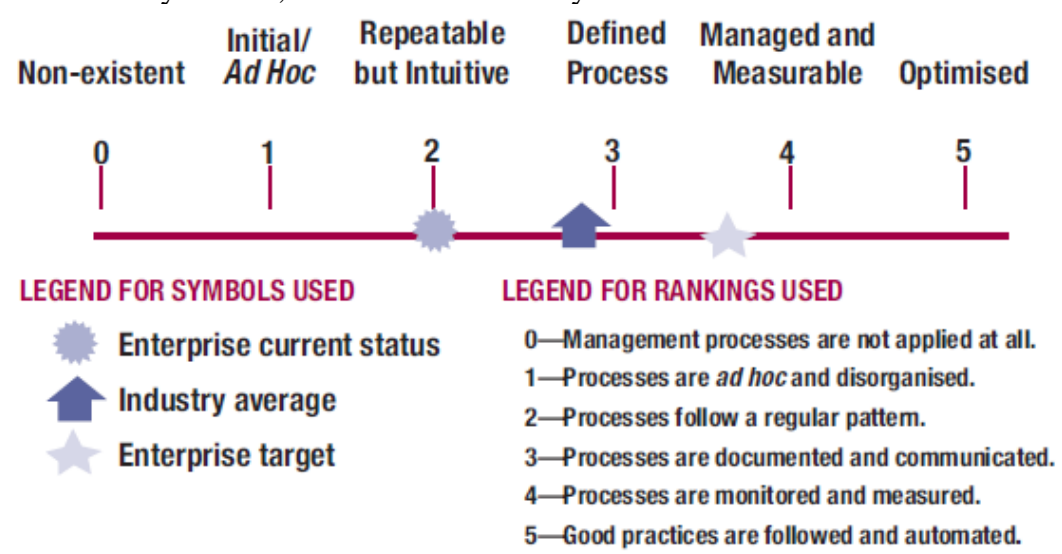

Fig. 1 - Maturity Model Representation Graph [5]

Capability Maturity Model / CMM is a method for mapping the process maturity level which is divided into 6 levels. Maturity level assessment using COBIT 4.1 maturity framework is carried out with the CMM Attribute Six Maturity Attribute approach: (1) Plans and Procedures; (2) Responsibility and Accountability; (3) Goal Setting and 
Measurement; (4) Skill and Expertise; Awareness and Communication; and (6) Tools and Automation [5] [6]. Maturity criteria for each attribute are developed from the Generic Maturity Attribute [6]. In the assessment process, each Information Technology Process is assessed using maturity attribute (ATR) criteria shown in Table 2 through Table 7 , as follows:

Table 2 - Maturity Criteria in the Plans \& Procedures Attributes (ATR1)

\begin{tabular}{c|l}
\hline Level & \multicolumn{1}{c}{ Plans \& Procedures } \\
\hline 3 & $\begin{array}{l}\text { The use of good practice has begun. In addition, the main processes have been established and are } \\
\text { complemented with the necessary policy and procedural support. } \\
\text { The processes in information technology governance are complete and have been implemented and well } \\
\text { documented. The policy has been set by the company management. Development and maintenance of } \\
\text { procedures have been carried out with reference to standards. } \\
\text { The organization has adopted external standards and best practices. Processes are documented in an automated } \\
\text { workflow. Policies and procedures have covered the entire process and allow for continuous improvement. }\end{array}$ \\
\hline
\end{tabular}

Table 3 - Maturity Criteria in the Responsibility \& Accountability Attributes (ATR2)

\begin{tabular}{c|l}
\hline Level & \multicolumn{1}{|c}{ Responsibility \& Accountability } \\
\hline 3 & $\begin{array}{l}\text { The responsibilities and accountability of the process have been defined. The process owner does not have } \\
\text { sufficient authority to carry out the task. }\end{array}$ \\
4 & $\begin{array}{l}\text { Process accountability has been established so that the process owner can fulfill his responsibilities in full. A } \\
\text { reward culture has been applied so that it becomes a motivation for positive action. } \\
\text { Process owner has sufficient authority to make decisions and take action. All components of the organization } \\
\text { have understood and carried out their responsibilities. }\end{array}$ \\
\hline
\end{tabular}

Table 4 - Maturity Criteria in the Goal Setting \& Measurement Attributes (ATR3)

\begin{tabular}{c|l}
\hline Level & \multicolumn{1}{c}{ Goal Setting \& Measurement } \\
\hline 3 & $\begin{array}{l}\text { Some effective steps have been implemented and there is a clear relationship with business objectives, but it } \\
\text { has not been well socialized. Process measurement has begun even though it has not been consistently applied. } \\
\text { The concept of the IT Balanced Scorecard has begun to be adopted, and the root cause analysis has begun to be } \\
\text { applied intuitively. }\end{array}$ \\
4 & $\begin{array}{l}\text { Effectiveness and efficiency have been measured and communicated and linked to business goals and IT } \\
\text { Strategic Plans. IT Balanced Scorecard has been applied in several areas, exceptions have been known by } \\
\text { management, and the implementation of root causes analysis has been standardized. Continuous improvement } \\
\text { has begun. } \\
\text { The IT performance measurement mechanism has been integrated and aligned with business objectives. } \\
\text { Exceptions are known by management and root cause analysis has been applied. Continual improvement has } \\
\text { been implemented. }\end{array}$ \\
\hline
\end{tabular}

Table 5- Maturity Criteria in the Skill \& Expertise Attributes (ATR4)

\begin{tabular}{c|l}
\hline Level & \multicolumn{1}{c}{ Skill \& Expertise } \\
\hline 3 & $\begin{array}{l}\text { Skill requirements for all fields have been defined and documented. A formal training plan has been prepared, } \\
\text { but it still depends on personal initiative. } \\
\text { Skill requirements have been regularly updated for all areas, proficiency has been confirmed for all critical areas, } \\
\text { and certification of expertise has been recommended. Established training techniques are implemented based } \\
\text { on training plans. Sharing knowledge has been recommended. The training involved internal experts. An } \\
\text { assessment of the effectiveness of the training has also been carried out. } \\
\text { The organization formally encourages continuous skill improvement. The improvement in skills takes into } \\
\text { account the suitability of personal targets and organizational goals. Education and training are conducted with } \\
\text { reference to best practices. Sharing knowledge between staff has become part of the organization's culture. } \\
\text { Knowledge-based systems are well implemented. }\end{array}$ \\
\hline
\end{tabular}


Table 6 - Maturity Criteria in the Awareness \& Communication Attributes (ATR5)

\begin{tabular}{c|l}
\hline Level & \multicolumn{1}{c}{ Awareness \& Communication } \\
\hline 3 & $\begin{array}{l}\text { There is already awareness to manage technology. Communication from management is carried out formally } \\
\text { There is an understanding of the complete requirements. Communication mechanisms and standard devices for } \\
\text { communicating have been established. }\end{array}$ \\
5 & $\begin{array}{l}\text { There is an understanding of requirements and foresight. Communication within the organization is proactive, } \\
\text { formal communication mechanisms have been established, and integrated communication tools have been } \\
\text { used. }\end{array}$ \\
\hline
\end{tabular}

Table 7 - Maturity Criteria in the Tools \& Automation Attributes (ATR6)

\begin{tabular}{c|l}
\hline Level & \multicolumn{1}{c}{ Tools \& Automation } \\
\hline 3 & $\begin{array}{l}\text { Plans for the use of standard tools in process automation already exist. Process automation tools have been } \\
\text { used, but not yet integrated. }\end{array}$ \\
4 & $\begin{array}{l}\text { Automation tools have been implemented according to plan. Some tools have been integrated with other tools. } \\
\text { Important areas and controls in the information technology governance process have been automated }\end{array}$ \\
5 & $\begin{array}{l}\text { Standard tools have been used in all components of the organization and are fully integrated. Tools have been } \\
\text { used to support process improvement efforts. The tool also has the ability to detect exceptions automatically. }\end{array}$ \\
\hline
\end{tabular}

\section{Methodology}

This research was conducted in three phases. In the first phase, a background analysis is carried out covering aspects of compliance and improving organizational performance. Mandatory regulations are mapped and made the basis of research.

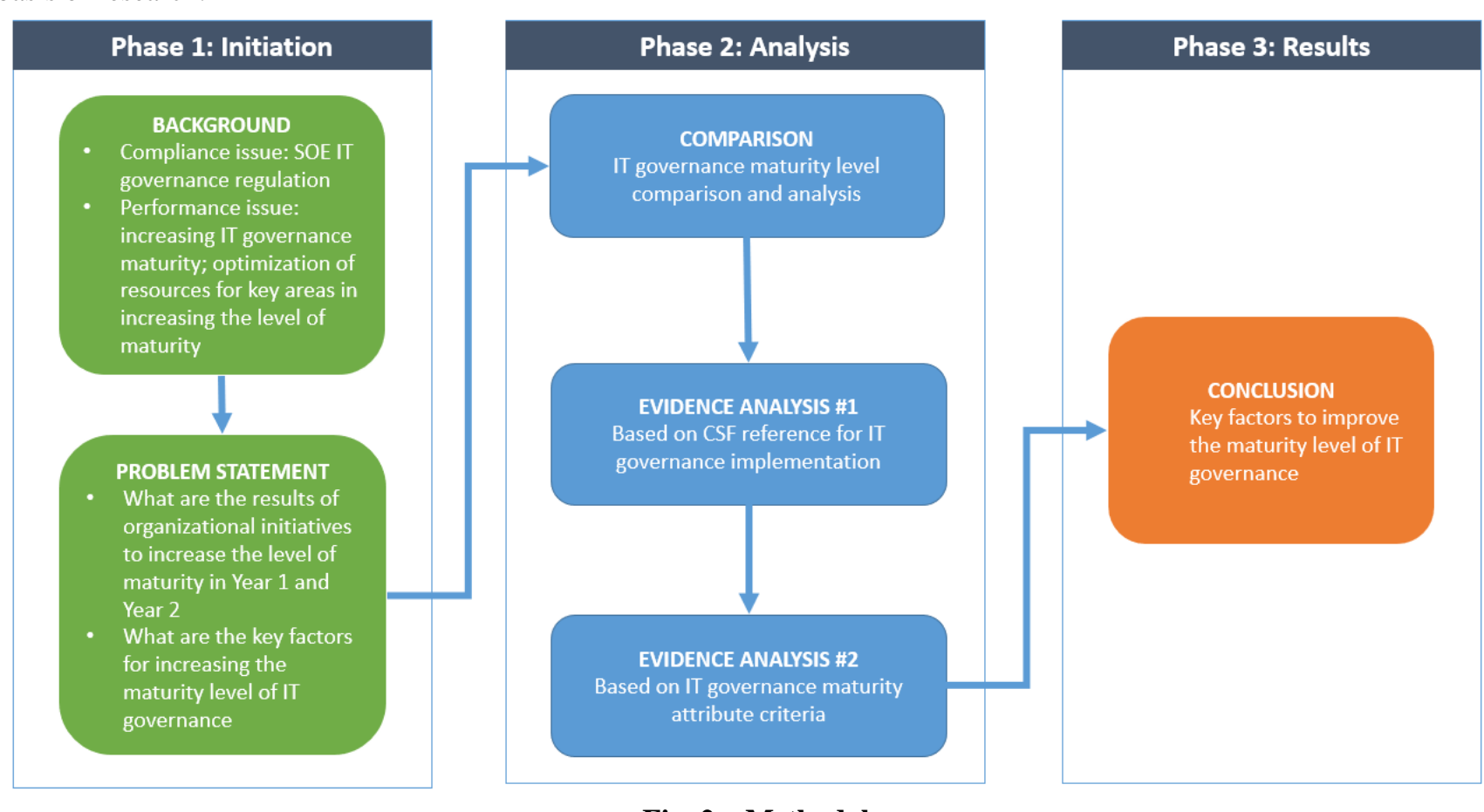

Fig. 2 - Methodology

In addition, issues related to technology support for organizational performance were identified through a review of the company's formal documents, as well as interviews with key stakeholders. In the second phase, comparison and analysis of the results of the evaluation of the maturity of information technology governance were carried out in year 1 and year 2. The analysis was carried out using two approaches. First, the analysis is based on the results of CSF identification in related studies. And then an analysis based on information technology governance attribute criteria is conducted.

Factor analysis of the increase in the value of maturity is carried out with an evidence-based comparative assessment approach. Comparative evidence of the assessment is carried out in processes that have increased the maturity value of information technology governance. Evidence included in the comparison table is new evidence / changes that existed at the time of assessment in Year 2.

The results of the Critical Success Factors study as summarized in Table 1 [13] and the Attributes and process achievement metrics are used as a reference in the analysis of factors increasing the maturity of each IT Process [5][6]. 
The results in the second phase form the basis for identifying the key factors in increasing the maturity level of corporate information technology governance.

\section{Result and Discussion}

\subsection{Comparison of Maturity Assessment Results in Year 1 and Year 2}

The assessment of governance maturity in Year 1 and Year 2 is carried out using the same method. The results of the assessment are summarized in Table 8, as follows:

Table 8 - Comparison of Maturity Assessment Results in Year 1 and Year 2

\begin{tabular}{|c|c|c|c|c|}
\hline Process ID & COBIT 4.1 Processes & Year 1 & Year 2 & $\Delta$ \\
\hline PO1 & Define a strategic IT plan & 3.42 & 3.58 & +0.17 \\
\hline $\mathrm{PO} 2$ & Define the information architecture & 3.17 & 3.42 & +0.25 \\
\hline $\mathrm{PO} 3$ & Determine technological direction & 3.33 & 3.42 & +0.08 \\
\hline $\mathrm{PO} 4$ & Define the IT processes, organization and relationships & 3.50 & 3.54 & +0.04 \\
\hline PO5 & Manage the IT investment & 3.33 & 3.42 & +0.08 \\
\hline PO6 & Communicate management aims and direction & 3.25 & 3.25 & 0.00 \\
\hline $\mathrm{PO} 7$ & Manage IT Human resources & 3.33 & 3.33 & 0.00 \\
\hline PO8 & Manage quality & 3.17 & 3.17 & 0.00 \\
\hline PO9 & Assess and manage IT risks & 3.33 & 3.33 & 0.00 \\
\hline PO10 & Manage projects & 3.33 & 3.38 & +0.04 \\
\hline AI1 & Identify automated solutions & 3.08 & 3.21 & +0.13 \\
\hline AI2 & Acquire and maintain application software & 3.17 & 3.33 & +0.17 \\
\hline $\mathrm{AI} 3$ & Acquire and maintain technology infrastructure & 3.17 & 3.29 & +0.13 \\
\hline AI4 & Enable operation and use & 3.00 & 3.13 & +0.13 \\
\hline AI5 & Procure IT resources & 3.25 & 3.25 & 0.00 \\
\hline AI6 & Manage changes & 3.17 & 3.17 & 0.00 \\
\hline AI7 & Install and accredit solutions and changes & 3.08 & 3.08 & 0.00 \\
\hline DS1 & Define and manage service levels & 3.08 & 3.08 & 0.00 \\
\hline DS2 & Manage third-party services & 3.25 & 3.25 & 0.00 \\
\hline DS3 & Manage performance and capacity & 3.17 & 3.17 & 0.00 \\
\hline DS4 & Ensure continuous service & 2.92 & 3.00 & +0.08 \\
\hline DS5 & Ensure systems security & 3.58 & 3.58 & 0.00 \\
\hline DS6 & Identify and allocate costs & 3.00 & 3.00 & 0.00 \\
\hline DS7 & Educate and train users & 3.00 & 3.08 & +0.08 \\
\hline DS8 & Manage service desk and incidents & 3.08 & 3.17 & +0.08 \\
\hline DS9 & Manage the configuration & 3.00 & 3.00 & 0.00 \\
\hline DS10 & Manage problems & 3.00 & 3.00 & 0.00 \\
\hline DS11 & Manage data & 3.00 & 3.00 & 0.00 \\
\hline DS12 & Manage the physical environment & 3.50 & 3.50 & 0.00 \\
\hline DS13 & Manage operations & 3.25 & 3.25 & 0.00 \\
\hline ME1 & Monitor and evaluate IT performance & 3.17 & 3.33 & +0.17 \\
\hline ME2 & Monitor and evaluate internal control & 3.25 & 3.25 & 0.00 \\
\hline ME3 & Ensure compliance with external requirements & 3.42 & 3.42 & 0.00 \\
\hline \multirow[t]{2}{*}{ ME4 } & Provide IT governance & 3.25 & 3.33 & +0.08 \\
\hline & Average & 3.21 & 3.26 & \\
\hline
\end{tabular}

The comparative table of the results of maturity assessment in Year 1 and Year 2 (Table 8.) shows the following:

1) The average value of information technology governance maturity in Year 2 has increased from 3.21 to 3.26 .

2) There is an increase in the average score of 0.05 during the period of 1 (one) year.

3) These results indicate that PT.X has succeeded in maintaining and increasing the maturity of its Information Technology Governance process at maturity level 3 (Defined Process). 
4) There are 15 processes that have increased the value of maturity, namely: PO Domain (PO1, PO2, PO3, PO4, PO5, PO10), AI Domain (AI1, AI2, AI3, AI4), DS Domain (DS4, DS7, DS8), and ME Domain (ME1, ME4).

\subsection{Evidence Analysis}

Next we do an analysis of the evidence from maturity assessment in year 1 and year 2 . The analysis focuses on processes where the maturity score rises.

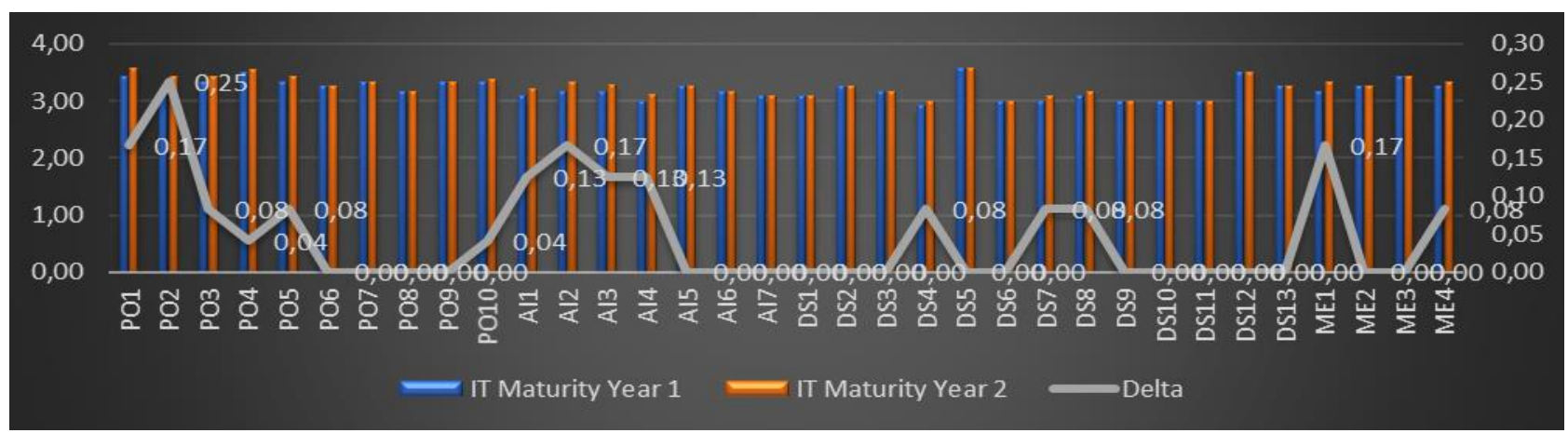

Fig. 3 - Process profiles with increased maturity scores

\subsubsection{Analysis of Plan and Organize (PO) Domain Maturity Assessment}

In this domain, processes with increased maturity scores are: PO1, PO2, PO3, PO4, PO5, and PO10. Evidence on the assessment of the PO1 process shows strong support from the leadership of PT X in relation to defining and aligning IT strategies and organizational strategies (CSF8, CSF9). In general, the evidence is also strongly related to the achievement metric of the PO1 process.

Table 9 - Analysis of Evidence on PO1 Process

\begin{tabular}{c|cll}
\hline Process ID & & \multicolumn{1}{c}{ Evidence } & \multicolumn{1}{c}{ Related Attribute and Metric } \\
\hline PO1 & $\bullet$ & Updates to the 5th Annual IT Master Plan & Attributes with increasing value of \\
& $\bullet$ & Strategic Planning Procedure & ATR1 and ATR2 \\
& $\bullet$ & IT Annual Planning Procedure & \\
& & $\begin{array}{l}\text { Decision of the Directors regarding Financial Job } \\
\text { Function }\end{array}$ & \\
\hline
\end{tabular}

Evidence on the PO2 assessment process was developed to standardize and integrate IT system management to optimize costs and information flow (CSF1). In general, the evidence is also closely related to the metrics for achieving the PO2 process.

Table 10 - Analysis of Evidence on PO2 Process

\begin{tabular}{c|cll}
\hline Process ID & & \multicolumn{1}{c}{ Evidence } & \multicolumn{1}{c}{ Related Attribute and Metric } \\
\hline PO2 & $\bullet$ & Information Architecture and Applications (Y1) & Attributes with increasing value of \\
& $\bullet$ & Archimate and ARCHI documentation & maturity: \\
& & & ATR1, ATR5, and ATR6 \\
\hline
\end{tabular}

Evidence on the assessment of the PO3 process is an effort to provide a structured IT infrastructure to facilitate the creation and sharing of IT services \& applications (CSF2). In general, the evidence is also strongly related to the metrics for achieving the $\mathrm{PO} 3$ process.

Table 11 - Analysis of Evidence on PO3 Process

\begin{tabular}{c|cll}
\hline Process ID & & \multicolumn{1}{c}{ Evidence } & \multicolumn{1}{c}{ Related Attribute and Metric } \\
\hline PO3 & $\bullet$ & Updates to the 5th Annual IT Master Plan & Attributes with increasing value of \\
& $\bullet$ & Information Architecture and Applications (Y1) & maturity: \\
& $\bullet$ & IT Strategic Planning Procedure & ATR1 \\
\hline
\end{tabular}


Evidence on the PO4 assessment process shows a formal step in institutionalizing a structure that ensures accountability \& flexibility for an organization's IT needs, including decision making and setting priorities (CSF12, CSF13, CSF14). In general, the evidence is also closely related to the metrics for achieving the PO4 process.

Table 12 - Analysis of Evidence on PO4 Process

\begin{tabular}{c|cll}
\hline Process ID & \multicolumn{1}{|c}{ Evidence } & \multicolumn{1}{c}{ Related Attribute and Metric } \\
\hline PO4 & $\bullet$ & $\begin{array}{l}\text { Decree of the Board of Directors regarding IT } \\
\text { Organizational Structure }\end{array}$ & $\begin{array}{l}\text { Attributes with increasing value of } \\
\text { maturity: } \\
\end{array}$ \\
\end{tabular}

Evidence on the assessment of the PO5 process shows a formal effort to clearly institutionalize the decisionmaking process and the determination of priorities related to IT (CSF13), as well as defining and aligning IT strategies and organizational strategies (CSF8). In general, the evidence is also strongly related to the metrics for achieving the PO5 process.

Table 13 - Analysis of Evidence on PO5 Process

\begin{tabular}{c|cll}
\hline Process ID & & \multicolumn{1}{|c}{ Evidence } & \multicolumn{1}{c}{ Related Attribute and Metric } \\
\hline PO5 & $\bullet$ & IT Annual Planning Management Procedure & Attributes with increasing value of \\
& $\bullet$ & Strategic Planning Management Procedure & maturity: \\
& & & ATR1 \\
\hline
\end{tabular}

Evidence on the assessment of the PO10 process is one of the formal efforts to use resources effectively to improve IT processes and their alignment with the business (CSF9). In general, the evidence is also closely related to the metrics for achieving the $\mathrm{PO} 10$ process.

Table 14 - Analysis of Evidence on PO10 Process

\begin{tabular}{c|cll}
\hline Process ID & & \multicolumn{1}{c}{ Evidence } & \multicolumn{1}{c}{ Related Attribute and Metric } \\
\hline PO10 & $\bullet$ & Procurement operational guidelines Type 1 & Attributes with increasing value of \\
& - & Procurement operational guidelines Type 2 & maturity: \\
& - & Project Management Procedures for Acquisition and & ATR1, ATR4 \\
& & Application Development & \\
& & Project Management Procedure for Implementing IT & \\
& & Infrastructure & \\
& - IT Consultancy Project Management Procedure & \\
& & Realization of IT HR Training related to Project & \\
\hline
\end{tabular}

\subsubsection{Analysis of Acquire and Implement (AI) Domain Maturity Assessment}

In this domain, processes with increased maturity scores are: AI1, AI2, AI3, and AI4. Evidence on the AI1 process assessment is an effort to develop staff to meet IT professional criteria (CSF4) in order to provide IT infrastructure to facilitate the creation and sharing of IT services \& applications (CSF2).

Table 15 - Analysis of Evidence on AI1 Process

\begin{tabular}{c|cll}
\hline Process ID & & \multicolumn{1}{c}{ Evidence } & \multicolumn{1}{c}{ Related Attribute and Metric } \\
\hline AI1 & $\bullet$ & IT Training List (Y1) & Attributes with increasing value of \\
& $\bullet$ & IT Training List (Y2) & maturity: \\
& & & ATR3, ATR4 \\
\hline
\end{tabular}

Evidence on the AI2 process assessment is an effort to develop staff to fit IT professional criteria (CSF4) in order to provide IT infrastructure to facilitate the creation and sharing of IT services \& applications (CSF2).

Table 16 - Analysis of Evidence on AI2 Process 


\begin{tabular}{c|cll}
\hline Process ID & \multicolumn{1}{|c}{ Evidence } & \multicolumn{1}{c}{ Related Attribute and Metric } \\
\hline AI2 & $\bullet$ & $\begin{array}{l}\text { Management of HR Applications is carried out by IT } \\
\text { Organizations }\end{array}$ & $\begin{array}{l}\text { Attributes with increasing value of } \\
\text { maturity: }\end{array}$ \\
& & ATR2, ATR3, and ATR4 \\
\hline
\end{tabular}

Evidence on the AI3 assessment process is an effort to develop staff to fit IT professional criteria (CSF4) in order to provide IT infrastructure to facilitate the creation and sharing of IT services \& applications (CSF2).

Table 17 - Analysis of Evidence on AI3 Process

\begin{tabular}{c|cll}
\hline Process ID & & \multicolumn{1}{c}{ Evidence } & \multicolumn{1}{c}{ Related Attribute and Metric } \\
\hline AI3 & $\bullet$ & IT Training List (Y1) & Attributes with increasing value of \\
& $\bullet$ & IT Training List (Y2) & maturity: \\
& & & ATR3, ATR4 \\
\hline
\end{tabular}

Evidence on the AI4 process assessment is one of the formal efforts to use resources effectively to improve IT processes and their alignment with the business (CSF9), as well as encourage and support 2-way communication and partnerships between IT \& business (CSF6).

Table 18 - Analysis of Evidence on AI4 Process

\begin{tabular}{c|cll}
\hline Process ID & \multicolumn{1}{c}{ Evidence } & \multicolumn{1}{c}{ Related Attribute and Metric } \\
\hline AI4 & $\bullet$ & $\begin{array}{l}\text { Project Management Procedures for Acquisition and } \\
\text { Application Development }\end{array}$ & $\begin{array}{l}\text { Attributes with increasing value of } \\
\text { maturity: }\end{array}$ \\
& $\bullet$ & $\begin{array}{l}\text { Project Management Procedure for Implementing IT } \\
\text { ATR1, ATR4 }\end{array}$ & \\
& & Infrastructure & \\
& - IT Consultancy Project Management Procedure & \\
& • IT Training List (Y1) & \\
\hline
\end{tabular}

\subsubsection{Analysis of Deliver and Support (DS) Domain Maturity Assessment}

In this domain, processes with increased maturity scores are: DS4, DS7, and DS8. Evidence in the DS4 process assessment shows strong organizational and technical efforts in managing risk appropriately (CSF3). In general, the evidence is also strongly related to the achievement metric of the DS4 process.

Table 19 - Analysis of Evidence on DS4 Process

\begin{tabular}{c|cll}
\hline Process ID & & \multicolumn{1}{|c}{ Evidence } & \multicolumn{1}{c}{ Related Attribute and Metric } \\
\hline DS4 & $\bullet$ & Routinely testing BCP every 6 months & Attributes with increasing value of \\
& $\bullet$ & DRC has entered the auction stage & maturity: \\
& $\bullet$ & IT Performance Report (Y1) & ATR1, ATR4 \\
\hline
\end{tabular}

Evidence on the DS7 process assessment is a formal effort to develop staff to meet IT professional criteria (CSF4), encourage and support 2 (two) communication and partnerships between IT \& business (CSF6), as well as providing socialization and education related to IT governance for strategic to operational levels (CSF7) In general, the evidence is also closely related to the metrics for achieving the DS7 process.

Table 20 - Analysis of Evidence on DS7 Process

\begin{tabular}{c|cll}
\hline Process ID & \multicolumn{1}{|c}{ Evidence } & \multicolumn{1}{c}{ Related Attribute and Metric } \\
\hline DS7 & $\bullet$ & IT Training List (Y1) & Attributes with increasing value of \\
& $\bullet$ & IT Training List (Y2) & maturity: \\
& $\bullet$ & In addition to training, a Workshop was also held. For & ATR4 \\
& & & \\
& & example: IT governance workshop & \\
& & Training / transfer of knowledge for IT Operations & \\
& staff in collaboration with third parties & \\
\hline
\end{tabular}


Evidence on the DS8 process assessment increases efforts to provide IT infrastructure to facilitate the creation and sharing of IT services \& applications (CSF2).

Table 21 - Analysis of Evidence on DS8 Process

\begin{tabular}{c|cll}
\hline Process ID & & \multicolumn{1}{c}{ Evidence } & \multicolumn{1}{c}{ Related Attribute and Metric } \\
\hline DS8 & $\bullet$ & IT Training List (Y1) & Attributes with increasing value of \\
& $\bullet$ & IT Training List (Y2) & maturity: \\
& $\bullet$ & Service excellence training & ATR4 \\
\hline
\end{tabular}

\subsubsection{Analysis of Monitor and Evaluate (ME) Domain Maturity Assessment}

In this domain, processes with increased maturity scores are: ME1 and ME4. Evidence on the ME1 process assessment shows formal efforts in institutionalizing performance indicators and measurement (CSF16).

Table 22 - Analysis of Evidence on ME1 Process

\begin{tabular}{c|cll}
\hline Process ID & & \multicolumn{1}{c}{ Evidence } & \multicolumn{1}{c}{ Related Attribute and Metric } \\
\hline ME1 & $\bullet$ & Updates to the 5th Annual IT Master Plan & Attributes with increasing value of \\
& $\bullet$ & IT Performance Management Procedure & maturity: \\
& $\bullet$ & $\begin{array}{l}\text { Capture of IT Asset Monitoring Applications } \\
\text { (infrastructure assets, networks, software, IT HR) }\end{array}$ & ATR1, ATR6 \\
\hline
\end{tabular}

Evidence on the ME4 process assessment is one of the efforts to involve key stakeholders (CSF17).

Table 23 - Analysis of Evidence on ME4 Process

\begin{tabular}{c|cll}
\hline Process ID & & \multicolumn{1}{|c}{ Evidence } & \multicolumn{1}{c}{ Related Attribute and Metric } \\
\hline ME4 & $\bullet$ & Capture Vulnerability Management Tools & Attributes with increasing value of \\
& $\bullet$ & Capture Monitoring of IT Assets Tools & maturity: \\
& - Capture IT Operations Management Tools & ATR6 & \\
& $\bullet$ & Capture e-Procurement & \\
\hline
\end{tabular}

\subsection{Identification of Key Factors for Improving the Maturity of the IT Governance Process}

Based on data on the maturity value of IT governance in Year 1 and Year 2, the comparison of maturity values, comparison and analysis of assessment evidence, as well as the analysis of attributes and metrics of each process, identified several factors increasing the maturity of PT X's IT governance in the First Year These 2. The initial identification of these enhancing factors is summarized in the Table 24:

Table 24 - Map of Support by CSF References and Attributes for Improving Maturity-level Processes

\begin{tabular}{|c|c|c|c|c|c|c|c|}
\hline Process ID & CSF Reference ID & ATR1 & ATR2 & ATR3 & ATR4 & ATR5 & ATR6 \\
\hline PO1 & $\begin{array}{l}\text { CSF8 } \\
\text { CSF9 }\end{array}$ & $\mathrm{X}$ & $\mathrm{X}$ & & & & \\
\hline $\mathrm{PO} 2$ & CSF1 & $X$ & & & & $X$ & $\mathrm{X}$ \\
\hline PO3 & CSF2 & $X$ & & & & & \\
\hline PO4 & $\begin{array}{l}\text { CSF12 } \\
\text { CSF13 } \\
\text { CSF14 }\end{array}$ & $\mathrm{X}$ & & & & & \\
\hline PO5 & CSF13 & $\mathrm{X}$ & & & & & \\
\hline PO10 & CSF9 & $\mathrm{X}$ & & & $\mathrm{X}$ & & \\
\hline AI1 & $\begin{array}{l}\text { CSF2 } \\
\text { CSF4 }\end{array}$ & & & $\mathrm{X}$ & $\mathrm{X}$ & & \\
\hline $\mathrm{AI} 2$ & $\begin{array}{l}\text { CSF2 } \\
\text { CSF4 }\end{array}$ & & $\mathrm{X}$ & $X$ & $\mathrm{X}$ & & \\
\hline $\mathrm{AI} 3$ & $\begin{array}{l}\text { CSF2 } \\
\text { CSF4 }\end{array}$ & & & $\mathrm{X}$ & $\mathrm{X}$ & & \\
\hline
\end{tabular}




\begin{tabular}{c|llll}
\hline AI4 & CSF6 & $\mathrm{X}$ & $\mathrm{X}$ \\
DS4 & CSF9 & & $\mathrm{X}$ \\
CSF3 & $\mathrm{X}$ & $\mathrm{X}$ \\
DS7 & CSF4 & & $\mathrm{X}$ & \\
& CSF7 & & & $\mathrm{X}$ \\
DS8 & CSF2 & & & $\mathrm{X}$ \\
ME1 & CSF16 & $\mathrm{X}$ & & \\
ME2 & CSF17 & & \\
\hline
\end{tabular}

From the contribution matrix, we get the weight of the contribution of each CSF Reference and Maturity Attribute to the overall increase in organizational maturity-level in year 2. The contribution weights of each CSF Reference are shown in Table 25.

Table 25 - Contribution of CSF Reference to Maturity-level

\begin{tabular}{c|cc}
\hline CSF Reference ID & Amount of Support to Process & $\%$ \\
\hline CSF1 & 1 & 4,35 \\
CSF2 & 5 & 21,72 \\
CSF3 & 1 & 4,35 \\
CSF4 & 4 & 17,39 \\
CSF6 & 1 & 4,35 \\
CSF7 & 1 & 4,35 \\
CSF8 & 1 & 4,35 \\
CSF9 & 3 & 13,04 \\
CSF12 & 1 & 4,35 \\
CSF13 & 2 & 8,7 \\
CSF14 & 1 & 4,35 \\
CSF16 & 1 & 4,35 \\
CSF17 & 1 & 4,35 \\
\hline
\end{tabular}

The contribution weights of each Maturity Attribute are shown in Table 26, as follows:

Table 26 - Contribution of Maturity Attribute to Maturity-level

\begin{tabular}{c|cc}
\hline Attribute ID & Amount of Support to Process & $\%$ \\
\hline ATR 1 & 9 & 34,6 \\
ATR 2 & 2 & 7,7 \\
ATR 3 & 3 & 11,54 \\
ATR 4 & 8 & 30,77 \\
ATR 5 & 1 & 3,85 \\
ATR 6 & 3 & 11,54 \\
\hline
\end{tabular}

\section{Conclusion}

In Year 1 the Maturity-level average score was 3.21. However, there is still one process that has a Maturity-level value below 3, namely DS4 Ensure Continuous Service (2.92). In Year 2, the entire IT process (34 processes) has reached a maturity score of 3 or more (Defined Process) with an average Maturity-level score of 3.26.

The results of the analysis and initial identification of factors strengthening the maturity of PT X's IT governance in the 2nd year, consisting of: CSF1, CSF2, CSF3, CSF4, CSF6, CSF7, CSF8, CSF9, CSF12, CSF13, CSF14, CSF16, and CSF17. The biggest contribution is in CSF2 Provision of IT infrastructure to facilitate the creation and sharing of IT services and applications (21.72\%); and CSF4 Staff development to meet IT professional criteria (17.39\%). Whereas the most dominant attribute of Maturity in increasing the value of Maturity-level is ATR1 Policies, Plan and Procedures (34.6\%) and ATR3 Goal Setting and Measurements (30.77\%). Overall PT X has intensively developed IT governance in aspects of people (CSF4), processes (ATR1, ATR3), and technology (CSF2). 
The results of this study can be a reference in evaluating and improving IT governance in other companies. Further research can be improved by using the latest COBIT framework and case studies applied to many state-owned enterprises. Changes in government regulations that direct the implementation of IT governance should also be considered in developing this research topic.

\section{References}

[1] Telecommunication Update (2018). “Teknologi Informasi Mendoring Transformasi BUMN Berkompetisi Secara Digital". Majalah SWA Online (6 Juli 2018), Retrieved from: https://swa.co.id/TelecommunicationUpdate/telecommunicationupdate/telkom-update/teknologi-informasimendorong-transformasi-bumn-berkompetisi-secara-digital

[2] Detik Finance (2013). "BUMN Jangan Gaptek, Harus Melek Teknologi dan Informasi”. Detik Online (1 Juli 2013). Retrieved from: https://finance.detik.com/berita-ekonomi-bisnis/d-2288662/bumn-jangan-gaptek-harusmelek-teknologi-dan-informasi

[3] Kementerian BUMN Republik Indonesia (2018). "Peraturan Menteri BUMN RI No. Per-02/MBU/02/2018 tentang Prinsip Tata Kelola TI Kementerian BUMN"

[4] Kementerian BUMN Republik Indonesia (2018). "Peraturan Menteri Badan Usaha Milik Negara No. Per03/MBU/2018 (perubahan atas peraturan Menteri BUMN RI No. Per-02/MBU/2013) tentang Panduan Penyusunan Pengelolaan Teknologi Informasi BUMN"

[5] IT Governance Institute (2007). "COBIT 4.1 Frameworks".

[6] IT Governance Institute (2003). "Board briefing on IT governance (2nd ed)".

[7] Grembergen, W. V (2004). "Strategies for information technology governance", PA: IGI Publishing Hershey, USA.

[8] Santos, Leonel, et al (2016). "A study on the impact of non-operational mechanism on the effectiveness of public information technology govenance". Revista de Administracao Brazil.

[9] Gil-García, J. R., \& Pardo, T. A (2005). "E-government success factors: mapping practical tools to theoretical foundations", Government Information Quarterly, Volume 22, Issue 2, Pages 187-216, 2005, https://doi.org/10.1016/j.giq.2005.02.001

[10] Alreemy, Z., et al (2016). "Critical success factors (CSFs) for information technology governance (ITG)", International Journal of Information Management, Volume 36, Issue 6, Part A, December 2016, Pages 907-916, http://dx.doi.org/10.1016/j.ijinfomgt.2016.05.017

[11] Raymond, Louis, et.al (2019). "Determinants and outcomes of IT governance in manufacturing SMEs: A strategic IT management perspective". International Journal of Accounting Information Systems

[12] Symons, C (2005). "IT Governance Framework". Forrester Best Practices, 29.

[13] Nfuka, E.N., et al (2010). "Critical Success Factors for Effective IT Governance in the Public Sector Organizations in a Developing Country: The Case of Tanzania", European Conference on Information Systems (ECIS) Proceedings.

[14] Weill, P., Ross, J. W (2004). "IT Governance: How Top Performers Manage IT Decision Rights for Superior Results". Massachusetts: Harvard Business School Press.

[15] Huang, Z., Zavarsky, P., \& Ruhl, R (2009). "An Efficient Framework for IT Controls of Bill 198 (Canada Sarbanes-Oxley) Compliance by Aligning COBIT 4.1, ITIL v3 and ISO/IEC 27002”. International Conference on Computational Science and Engineering, doi:10.1109/cse.2009.336

[16] Grembergen, W.V (2004). "IT Governance and Its Mechanism”, Information Systems Control Journal, Volume 1

[17] De Haes, S., Grembergen, W.V (2005). "IT Governance Structures, Processes and Relational Mechanisms: Achieving IT/Business Alignment in a Major Belgian Financial Group", Proceedings of the 38th Hawaii International Conference on System Sciences.

[18] Jonathan, et.al (2017). "IT Governance Analysis and Design of Microfinance Institution Using COBIT 5 Framework Evaluate, Direct, Monitor (EDM) and Align, Plan, and Organize (APO) Domains". International Journal of Innovation in Enterprise System / IJIES, Volume 01, Issue 01, July2017. https://ijies.sie.telkomuniversity.ac.id/index.php/IJIES/article/download/3/1

[19] Sirisomboonsuk, et.al (2018). "Relationships between project governance and information technology governance and their impact on project performance". International Journal of Project Management 36 (2018) 287-300

[20] Otero, A.R (2015). “An information security control assessment methodology for organizations' financial information”. International Journal of Accounting Information Systems. 